\title{
The Concept of Feminist Justice in African Philosophy: A Critical Exposition of Dukor's Propositions on African Cultural Values
}

\author{
Ani Casimir \\ Department of Philosophy, Institute of African Studies, University of Nigeria, Nsukka, Nigeria \\ Email: taissesaiafrica@rocketmail.com, cepperngo@yahoo.com \\ Received October $8^{\text {th }}$, 2012; revised November $10^{\text {th }}$, 2012; accepted November $24^{\text {th }}, 2012$
}

\begin{abstract}
Having taken note of, and critically analyzed, Professor Maduabuchi Dukor's epochal work entitled "Theistic Humanism of African philosophy-the great debate on substance and method of philosophy" (2010), I am much encouraged and rationally convinced that he has succeeded in building the core critical and essential foundational pillars of what can safely pass for professional African philosophy, though much remains to be done by way of further research from other scholars. Based upon that conviction and the great prospects that the African philosophy project breakthrough holds for every African philosopher in the global village, I am also motivated to take a closer look at, and carry out a critical exposition of the concept of justice in the context of African cultural values, using the propositions of what he calls the canons of cultural values that are native to African philosophy. These cultural values define African identity and delineate Africa's contributions to the advancement of the global ideas of justice, axiology, gender and globalization. The essence and methodology of this article, therefore, will lift the relevant thematic thrusts and arguments made by the erudite Professor of African philosophy to "properly locate African philosophy in the context of globalism, cosmopolitanism, science and what it could contribute to emerging global culture” (Dukor, 2010: p. ix). The central point of this critical exposition is that his theistic inspired cultural humanism has enhanced the global understanding of not only justice but feminist rights and the urgent needs for African philosophy to make its contributions towards the emancipation of and empowerment of women both in the continent and globally. The feminist search for justice, according to Dukor, is "the current global pool where the African is needed urgently to intervene", since "feminism and women liberation has truncated the equilibrium and balance of relations between man and woman. African contribution to this class struggle between man and woman is a neutral one that absorbs the man and woman to their respective natural places in the nature's womb". Women's search for global justice and the struggle to have their human rights recognized as a part of mankind's gender balancing process would be philosophically enriched by Professor Dukor's cultural value propositions and canons of justice.
\end{abstract}

Keywords: African Philosophy; Justice; Gender; Feminism; African Cultural Values

\section{Introduction}

All the rigorous and well made arguments marshaled out by scholars to defend and project African philosophy have prepared the ground for the establishment of African identity, the African personality, the African values and how, as a corpus of knowledge stretching over the millennia has, in its own right, sought to contribute positively to the growth of world knowledge in philosophy, science and other areas of human endeavor. African philosophy has therefore entered a new pro-active phase of its growth when more rigorous and profound creative epistemic efforts needed to be made in defining the knowledge portals where it could contribute seminally to global philosophy and help in the solution of problems that challenge mankind such as de-valuation of morals and values, globalization and injustice against women. Professor Dukor (2010: p. vii) elaborates on this pro-active, global and creative responsibility of African philosophy which makes it to be outward bound in its majestic march towards global documentation, identity and recognition as an authentic philosophy and philosophizing from Africans and western scholars interested in studying African philosophy:

It is important to note that the vigorous and strenuous efforts exerted in defense of African philosophy produced arguments in defense of African freedom. Yet African philosophy is not a reclusive philosophy that subsists as a philosophy of primitive or ancient people of Africa or the philosophy of Africans that serves the aesthetics, ethical, political, social and technological needs of the Africans alone. It is a philosophy of the post-modern age justified and sanctioned by postmodernism as doctrine of postimperialist new world order. In some unique and particular sense, African philosophy in the global village highlights some special features of what I call theistic humanism in all areas of human life-aesthetics, ethics and science-which 1 think are of global significance and could make the earth a better place for human habitat. African philosophy in the global village is therefore theistic humanism of African philosophy and secondly cosmopolitan philosophy. In this postmodern era, international community recognizes what individuals, societies; nations could contribute to united world. Under the current aegis of the 
United Nations, periods and dispersions of slavery, colonialism and racism are now bygone eras. The regime of superiority of "our races over the rest and the dominations of the "other" with the ideology of monotheistic reason have all been castrated by the superior postmodern reason that every culture has a legitimate place in a free world. Above all, every culture has something to contribute to values, literature or history, science and technology. African philosophy in the global village as a cosmopolitan philosophy therefore contributes meaningfully to the world's ethical, literary and scientific heritage. This the sense in which we discuss the African philosophical contributions in axiology, literature and science.

The morphology of axiological values are informed and under girded from the animistic and transcendental epistemology of African philosophy which help to define the African concept of identity, justice and human cultural values. The works of Professor Dukor which capture these philosophical pillars are "artistic symbols and aesthetic values in African philosophy" (2009); proposition of African cultural values' (2010); “the concept of justice in African philosophy” (2006); and “African philosophy in the global village-which embodies and captures the essential philosophy of all the foregoing works in their proactivity, creativity, existentialism and their pan psychic rationality. The point is that the concepts of art and aesthetic values flow naturally from the African man's concept of God and his understanding of the universe of his nature, environment and society. This is the quidity of theistic humanism and metaphysic of the African that is well embedded in philosophy. The African mind, which is at the heart of the philosophical enterprise has axiological values that "uphold fundamental human rights and consensual democracy and defines the concept of justice from an animistic and communal perspectives" (Dukor: p. viii). According to Dukor: "the same transcendental and animistic foundation and paradigm define the complexion of arts and aesthetics in African philosophy”. In furthering this idea, we must take a research note that Professor Dukor's concept of "pan psychic rationality" evolved earlier and was first captured in the following works "theistic pan psychic rationality of African History”; "theistic pan-psychic communicative Rationality" and "Life-Here-after Poetics and metaphysics". In his words, Professor Dukor elaborates on this concept of panpsychic rationality with a deep thematic emphasis on its pervasive and cross-cutting penetration of African conceptual moulds, values, mores, attitudes and approaches to the process of philosophizing:

The idea of theistic pan psychic rationality is meant to be used to justify every facet of study in African philosophy-we call it theistic pan psychic because the framework of understanding for understanding the African mind is both theistic and pan psychic are irreconcilable factors in Christianity and some philosophies. Literature is the mirror of a people's experience and life using the medium of language propositions poetry. African literature incidentally is suffused and characterized by theistic animism and pan psychism so also is its history. Because of its God-intoxicated nature, the African history, literature and means of communication are theistic, pantheistic, communistic and pan psychic.

It is in the light of these theistic and pan psychic foundational values and established foundational features of African philosophy that one should start thinking and working towards the role African philosophy should play in solving not only the traditional problems of philosophy but also the challenges facing mankind in the 21 century. The pillars and canons of theistic humanism and pan psychism combine to define, inform, under gird and underpin African philosophy so that scholars and philosophers of African descent should be motivated to start thinking of reconstructing the role and contributions of the discipline in bettering the lot of humanity in the new millennium. The significance of African philosophy in the global village can only be determined, assessed and evaluated by its evidence based contributions towards enhancing the quality of human discourse; which enhancement could only come about through its millennia-distilled cultural and axiological values that distinguish its humanism, humanness and humanity. What should be the contributions of African philosophy towards the global village and human development? In response, Professor Dukor's works in this direction which sought to help us to determine this equation are well documented and used in University Faculties globally: "Globalization and African identity" (2008); "Feminism in theistic humanism” (2007); "Epistemology of outer space” (2009); "Symbol and symbolism in infoTech epistemology” (2008); and, "Philosophy and African salvation" (2007). Describing the content of the template of what should be the role of African philosophy was wired through the basic stream of Professor Dukor's vision for African philosophy in the global village, as captured by him in the introduction of the book, "African philosophy in the global villag":

The vision of this work is to locate African philosophy in the context of globalism, cosmopolitanism, and science and what it could contribute to the emerging global culture. The practices of retrogressive cultures and traditions have been responsible for the lack of African science and the inability of the Africans to contribute to scientific growth. Many factors like atavism, selfishness, witchcraft and sorcery have contributed a lot to the retardation of African civilization not only to science but also to the epistemology or science of the outer spaces, where the local folks have perfected somewhat the artistic and mystical vehicles for journey to and from outer spaces. Another area of the current global pool where the African is needed urgently to intervene is the area of feminism and women liberation which has truncated the equilibrium and balance of relations between man and woman. African contribution to this class struggle between man and woman is a neutral one that absorbs the man and the woman to their repesctive natural places in the nature's womb (Dukor: p. ix).

Professor Dukor's theistic and humanistic propositions on African cultural values and categories form the bedrock of the African conceptual approach to African identity, feminism and the place of African philosophy in achieving human development under the rapid march of globalization. A Critical exposition of these propositions should constitute the focus of the article for further elucidation.

\section{Propositions on African Cultural Values 15-18}

In the first place there is no uniformity of African cultural values in the way one could accept the uniformity of western or 
Islamic cultural values that established the western or Islamic concepts of jurisprudence, laws or justice. This does not negate the fact that one could effectively write or accept the existence of values that are inherently African with a multiplicity and diversity that summarizes common essentials. The reason flows principally from the fact that they are ontological, ontic and epistemic (Dukor: p. 15). In other words, African values are concerned with moral normative values in the cultural sense. The African concept of value goes beyond and is deeper than the western ethical conception of value since every thing in African world view has a value or worth ascribed to it from its ontological relationship with God and the universe of beings. Throwing more light to this unique sense of values, Professor Dukor writes:

Value is such a broad concept that mistake is often made when seen only from the point of ethical values. However, the values of a people go beyond ethics to values of technology, architecture, food habit, poetry, music, sculpture, painting, farming, swimming and a whole of arts. These are values while the later belong to what is called moral normative value.

Going further to throw more light to this concept of value in African philosophy is important. As such Igboin (2011: p. 1) gives another supportive and penetrating insight to that of Dukor:

Values may be ideas that propel man's daily actions. In other words, they are the standard which members of the community adhere to in their personal and communal interaction towards the achievement of the goals. It is they that determine those who are to be praised or reprimanded for their actions. In another sense, values refer to what is "good" or "desired". In the descriptive sense, value can mean the worth of something as when an article is evaluated. Values can be institutional and cherished by individual and by a group of people. Values can refer to the usefulness of a thing which is a function of choice-making. That is, there are options opened to one from which a choice is made. In so far as values are universal, they can be material, spiritual, religious, moral, aesthetic, communal or individualistic. Another feature is that values are found in all religions. People's values are largely based upon traditional religious and moral principles that they cling to. Values can be influenced by what we see and hear.

Supporting Professor Dukor's concept of African values is the views of Kwame Gyekye as reviewed by Lolli (2010) in her blog' Around the world' wherein Gyekye has identified religious values, family values, aesthetic values as central to African society. Each value is illuminated through the use of oftenrepeated African proverbs and folktales, as well as anecdotal and historical examples of the value in practice. This is a unique value which, according to Lolli, Kwame Gyekye illustrates in the following way:

Africans recognize the dignity of the human being and, in consequence, hold a deep and unrelenting concern for human welfare and happiness ... Recognition of the value of humanity is intrinsically linked with recognition of the unity of all people, whether or not they are biologically related” (p. 23). To underline his point, Gyekye quotes an old Akan maxim: "It is the human being that counts; I call upon gold, it answers not; I call upon cloth, it answer not; it is the human being that counts.

African cultural values could be propositioned into categories through "logical analysis in terms of propositions, predication and entailement and finally into magisterial, legislative and universal law-like statements or propositions which can be true or false” (Dukor). In this direction, consequently, one could state that are different categories of cultural values in Africa. There are two main categories of African cultural values as identified by this perspective which are-the moral normative values and the non-moral normative values. The first set are those ethical or axiological values whereas the second set constitute aesthetic and artistic values that define the non-moral normative values found in African philosophy embedded in folklores, proverbs and wise sayings on one hand and on the other hand are propositions within the kinship or communalistic system (Dukor: pp. 15-16). The unique concept of African cultural values has a dialectical relationship with theistic humanism as propounded by Professor Maduabuchi Dukor as it the defining principle of African cultural values and from it springs what he calls community values such as kinship, extended family, communitarianism and social values. At the same time theistic humanism gives rise to the second set known as aesthetic values such as food and work habit, agricultural and architectural values, music, artistic values and celebration of life. He called the first set "community consciousness" while he called the second as "aesthetic consciousness" with both having their roots in "the religious, scientific and existential value" which he called theistic humanism. Both consciousness-the community and the aesthetic-complement and supplement each as they are not exclusive but inclusive in their functional cooperation, collaboration and synergy in maintaining the happiness, peace, security and progress of the African society.

\section{The African Concept of Justice}

The concept of justice in African is based on communalistic, folk and communitarian values and permeate the entire spectrum of African society, culture and affecting the African approach to human development. Though it is a reflection of African values, it still approximates to the western concept of justice (Dukor, 2010: p. 21). Various studies and researches confirm this proximity and aproximity between the African and the western concepts of justice as reflected in the works of Professor Dukor, Okafor and Oraegbunam. In the views of Professor Dukor, this is more explicit in the works of Rouseau and Locke:

Close study shows that in pre-political African societies the concept of justice is similar to John Locke's and Rouseau's ideas. Locke's state of nature is not as violent as that of Hobbes'. He believes that there is no natural proclivity for men to hurt one another other. For Hobbes no steps on somebody's toes just for the fun but only to get an advantage: quite characteristic of his state of nature as "men living together according to reason, without a common superior on earth with authority to judge between them". This state of peace, goodwill, mutual assistance and preservation hunges on the law of nature. In J. J Rouseau Emile, the idea of the natural man is that man is by nature good. If he is wicked it is because bad upbring and environment have corrupted him. He says: God 
makes all things good; man meddles with them and becomes evil'. In his social contract he says "man was born free and every where he is in chains”. Both Locke's and Rouseau's ideas of man's natural goodness collided with the traditional doctrines of original sin and redemption, and more importantly, with the traditional African thought on man's natural goodness and initial communion with God. Various myths in Africa tell us that God once lived among the people until man misused his freewill. These myths not only illustrate the doctrine of original sin and redemption but also show that God, like in the Roman and Greek literatures, is the author of man and law as well as the symbol of justice. The African idea of natural and law is more or less the same with the ancient Roman or Greek interpretation of the natural law and the scholastics (Thomas Aquinas and St. Augustine) treatises on Divine laws and justice. Hence for the African, the Roman or St Augustine, God is the author of any law that is worth that name and the precepts of law are discoverable by reason or apriori.

In essence, Professor Dukor is emphasizing the fact that African concept of justice flows from the the pillars of religion, ethics and the supernatural in African philosophy. This where the values that define the values of justice and permeate the concept of gender. Thus the formulation and application of justice draws from the folklore, myths and languages of the African as identified in different cultures in Africa. For example, according to Dukor (2010: p. 21) the "Igbo and Akran folk philosophy is in accord with reason and x-rays a clear absence of Hobbesian war order. Its ethical and political dynamics constitute a check against loose control of the societal purpose. The theory of communalism is clearly applicable to different groups and norms of traditional African societies. The principle underlying this maxim is the celebrated utilitarian principle (of either Bentham or Mill) that the greatest good of the majority must always be sought; it also implies that the public necessity is greater than private necessity". The force of moral suasion and personal responsibility makes it superfluous to call the police to arrest people who have transgressed the communal laws that define justice issues in African societies since the sense of "moral responsibility, communalism or kinship takes care of deviations" (Dukor, 2010: p. 17).

The same concept of justice as illustrated by Professor Dukor's "theistic humanism-the African belief in the supernatural beings and also man; the principle or doctrine designating African ideas of man, God and the universe-inform also the ethical and juridical conception of gender justice and other aspects of law in places like Igboland. The Igbo concept of justice is embodied in the word-value known as "Omenani" - the laws of the society according to the revelations from the elders or the wise ones who are into touch with God and the universal beings” (Ani, 2008: p. 23). This omenani is compared to Kelson's theory of justice by Oraegbunam (2011) and variously called the "grundnorm”, “omenala”, “akankwumoto” (a just person); "ikpekwumoto" (a just law or judgement). In the following deposition, Oraegbunam not only agrees with Professor Dukor's theistic humanistic basis of justice in African philosophy, but also makes strong allusions to the proverbial intrusions and extrusions of the law in pre-modern African societies thus:

Be that as it may, Nzomiwu observes that as the history of the Igbo people progressed, the words "akankwumoto" and "ikpenkwumoto" gathered a metaphorical and a more comprehensive meaning. According to this development, justice becomes any action that conforms to the omenala (tradition), which constitutes the grundnorm, to use kelson's terminology. Justice, thus, becomes conformity with the requirements of the custom and tradition. A man who keeps the injunctions of Omenala which contains the duties of a citizen in all its ramifications is regarded as a just man. In the same vein, the word "ikpenkwumoto" became a judgement that conforms to the tradition (omenala). In other words, any judgment that is not consistent with the Omenala is not constitutional and as such null and void. Such a judgment cannot be binding on any party. It somewhat violates what the English law would call the principle of "stare decisis" and it is bound to be unjust (mmegbu) which condition aims at or attempts to deprive one of his life or entitlements. Besides, the Igbo sense of justice is quite condensed in Igbo oral tradition. Illustrations from two of the sources of this tradition may be helpful. Thus, justice is expressed in Igbo proverbs and names. Let us take them one by one. Among the Igbo people, the use of proverbs in the communication of ideas is very invaluable. A proverb for them is a figure of speech in which many lofty ideas and philosophy are concealed and congealed. In referring to African proverbs, Herskovits regards them as constituting the "grammar of values". 12 In proverbs are condensed the nitty gritties of Igbo customs, ethical standards, traditional wisdom, and wise sayings. For the Igbo, proverbs constitute the spice or salt of human communication (nnu e ji eri okwu). Certainly, the Igbo understanding of justice in all its ramifications is well expressed in various proverbs. Let us now give some instances of Igbo proverbs that explain different aspects of Igbo conception of justice. Firstly, there is a group of proverbs that emphasize the Igbo sociological philosophy of live-and-let-live, harmony, peaceful coexistence, and consideration for the needs of others. Examples of these proverbs include "Egbe bere ugo bere nke si ibe ya ebela nku kwapu ya" (let the kite perch and let the eagle perch also, whichever (let the kite perch and let the eagle perch also, whichever denies the other its perching right, let its wings break off).

The African conception of justice according to Dukor is therefore "philosophically presupposed in its divine conception of natural law: natural and justice should be construed as being the same with divine law and justice-this accounts for its concept of divine justice in being more or less the same as that found in the Greek and Roman worlds” (Dukor, 2010: p. 30). Dukor concludes that "the corpus of African divine laws covers rights and wrongs, duties and obligations (Dukor, 2010: p. 29); there are two main ways of executing justice in a typical African community-one is through the use of curse and the other is through the use of formal oaths. The basic principle in the use of curse is that if a person is guilty, evil will befall him according to the words used in cursing him. The operative principle is that only a person of higher moral and social status can effectively curse one of a lower moral and social status but not vice versa. Formal oaths are used as method of establishing and maintaining good human relations. The due process of African traditional law, like oath taking and so on, is no respecter of 
persons. Every person is ontologically equal in the eyes of the gods (Dukor, 2010: p. 28). Bolaji Idowu (1975; Dukor, 2010: p. 29) concurs philosophically and ontologically with Professor Dukor on this theistic source and basis of the African concept of justice:

The whole concept of justice is based upon the fact that world belongs to a deity; that the social and moral orders are his ordinance and that he is far above all divisions into races, ethnic groups, clan differences or political partisanships.

\section{Feminism in African Philosophy 147-156}

The concept of feminist justice in African philosophy is logically inclusive as well as naturally exclusive of the early concepts of feminism in which women activists sought to disrupt the natural order of nature by dissuading women from marriage or giving birth, taking care of babies or carrying out their natural domestic chores. I have argued seriously in a presentation that basic African sense of justice flows from African values of respect for womanhood as the physical representation of mother earth that gave us birth and the being that could complete the human hood of man through the mystery of reproduction and complimentarity (Ani C, 2007: pp. 23-26.) Professor Maduabuch Dukor (2010: p. 27) consummates this philosophical quest for justice for the African woman by giving an insight which is as mysterious as it is cosmological and ontological thus:

The relation of man to woman in African context is cultural and metaphysical. Just like the Genesis account of creation, African cosmology and ontology see the concept of womanhood as an extraction from the concept of manhood. Similarly, social and political organizations are culturally patterned to reflect the mystery and superiority of manhood. Justice is also maintained in the communal ownership of lands and landed properties and their equitable distributions.

Gender discourse in African philosophy has been tainted by what Professor Dukor calls its "loss of focus because of the tendency to leave out the gaps in culture created by colonial experience, modernity's assaults and un-africanness in ontology and essence" (147). He goes on to state that: "the fulcrum for a legitimate feminist doctrine is theistic humanism, the philosophy of African philosophy that exposes the epistemological and metaphysical basis of rightful and ethical place of women in the society without injury, injustice and abuse on womanhood. Theistic humanism as an ontology and cosmology abhors class struggle between husbands and wives, sons and daughters etc. Class struggle between men and women degenerated from the oneness of being ontology and gender community where husbands and wives were happily married with different complementary social roles for the preservation of society". In essence his unique contributions to gender discourse is based on the superstructure of humanism and African theism that validates and sustains the concept feminine justice, gender balance nd gives womanhood gender value in the social context. However it is to be noted that postmodernism, colonialism, post modernity and globalization have distorted and created problems with this pure gender concept suffused with African values. This has created the problems of gender injustice and marital instability which are fundamentally common social problems resulting from western civilization and values.

\section{African Identity, Challenges and Globalization-Gender Injustice}

As we could infer from the foregoing, Professor Dukor has excavated the truth that the search for African identity and core values has revealed the crisis of modern African wherein the continent and its children have deserted the core values that define our identity and that would have sustained its people un der the surge of globalization. This means going back to our Africanness and basing our conceptions and actions on the superstructure of theistic humanism which restores our purity and identity. This should constitute a change in paradigm in inquiry and methodological approach to the challenges of gender injustice in the context of globalization. This is what I have defined as an African perspective. Such African social scientific approach to African identity, gender science, culture and personality are regarded to be part of a concerted struggle to question and challenge Western effort to suppress and dominate Africans, their philosophy and identity in the face of globalization. It is further intended to be used by African scholars in the social sciences to be theoretically and methodologically wholistic in protecting, promoting and liberating Africans from another bout of neocolonization and help the African man and woman to focus on the need for Africans to rediscover who they are, what values they have and what should be the ideal principles that define gender relations in the continent. This is what Professor Dukor has succeeded in doing by preparing the philosophical, ontological, methodological grounds that would define a new way of redefining gender ideology, relationships and justice systems independent of the imposed and assimilated Western values, philosophy, ways of thinking, behaving and socio-economic management. In other words, he challenges African scholars to be ontologically and cosmologically vibrant, dynamic and relevant in solving problems of modernity and globalization.

In attempting to redefine this African perspectives and methods to globalization and modern problems, Lassiter (1997) gives another supportive thesis and explains why there is tendency by scholars emerging from the intimidating psychology of neocolonial scholarship are afraid to apply and work with this value and ontology based perspective which is purely African:

From the early sixties to the present, African scholars outside the social sciences have consistently claimed that there have been, are and will continue to be widespread psychological and cultural themes and patterns that there are unique to sub-Saharan Africa. They also argue that these broad themes and patterns are undergoing rapid change in a similar manner and most often for the worse throughout most of the continent. The strength of their commitment to these concepts is reflected in the fact that the scholars persist in their efforts despite a historical intellectual context that eschews such inquiry. This survey reveals they have done so to clarify and extol the virtues of what it means to be African in the face of increasing global Westernization, and to identify and promote the importance of "Africanness" in African national and regional development. African scholars also seek to reassert 
Africa's importance in the broader philosophical and cultural evolution of humankind. Although some of the works contain significant methodological shortcomings which will be addressed below, most of the scholars' assertions and arguments are well-reasoned and extremely compelling. South African Professor and former Deputy Vice-Chancellor at the University of the Witswatersrand M. W. Makgoba (1997), using a more practical and problem-focused approach to bring matters back to the social scientists, sees a prominent and practical role for African social scientists in the post-colonial reconstruction of Africa. He writes: Africa has faced some of the great social changes in this century in terms of race, ethnicity, politics, violence, labour relations and industrialisation. Graduates in the social sciences are going to be a critical component to the success of African democracies as they struggle to emerge from the mess in which they have been. Universities are not only essential for the training and nurturing of highly-skilled scholars in this area, but are poised to make a unique contribution to the overall development of postcolonial Africa.

Thus post modernism and globalization could be said to have created the current problems of modern gender injustice and crisis of African identity. The modern justice systems in African are colonially inspired and most are yet to be reformed in reflection of the core African theistic human values of justice. These theistic human values of justice are what would give African womanhood and gender concepts a renewed rigor in analytical purity resulting in new institutions and social structures that would create a new gender balance and justice. This will make case for new African indigenous justice system that would institutionalize the idea and doctrine of African based jurisprudential system that give genuine control of African justice institutions to Africans and be used to achieve transformative justice for all. The difference between African concept of justice, which is ontologically theistic and humanistic, and the western concept, which is individualistic and exclusive (One person wins and others lose), is well brought out by Elechi Okoh (2005) in his "human rights and the African indigenous justice system paper:

Despite the dominant position of African states in social control, African indigenous institutions of social control remain relevant in the affairs of the people. This is especially so in the rural areas of Africa where the majority of the people reside. African peoples' disappointment with the colonial sponsored justice system, derive mostly from their perception of the system's concept and practice as alien, and prone to abuse and corruption, and antithetical to the African concept and practice of justice. African indigenous justice system employs restorative and transformative principles in conflict resolution. Victims, offenders and the entire community are involved and participate in the definition of harm and search for resolution acceptable to all stakeholders. This position overlooks the inherent differences in world-view, and the role of culture in the conception and administration of justice. Findings from this study indicate that the restoration of rights, dignity, interests and wellbeing of victims, offenders, and the entire community is the goal of African indigenous justice system ... Again, the victims' needs for information, validation, social support, vindication, are the starting points

\section{of African justice.}

Theistic humanistic paradigm of African gender discourse flows from African gender philosophy which is its unique justice system that derives from the unity of consciousness or wholistic personality of the African. What constitutes this wholistic personality and dialectical link to African concept of gender has been further illuminated by Dukor (2010: p. 159):

Philosophy analytically and intuitively captures in wholistic manner the human personality as a product of culture; the empiricist and positivist comprehension of feminist ideology is largely empirical and non-supernatural, while the African and the rationalist understanding of feminism is based on God's creation that created woman's nature in man's nature. The metaphysical foundation of feminist discourse in pre-colonial African philosophy is therefore that man and woman are two separate species in one, in the generic sense but physically endowed with different sexualities.

One can surmise that the theistic humanistic paradigm is effectively related to and derives authenticity from the African values of justice, freedom, equity and fairness between the man and woman in the society. Thus while the western doctrine of sexism and sexuality are imploding with the idea of a recurring conflict between men and women that makes their relationship adversarial and exclusive in metaphysical functionality the African gender approach is existentially inclusive, supportive, cooperative and metaphysical derived from the African value of respect and worship of the earth as mother which is refered to as "mother earth" (Dukor, 2010: p. 151). Thus the ascribed problems which western women liberation see as the traditional problems of women in the world today are foreign to African gender discourse and philosophy since they are since as self inflicted, semantical linguistic and philosophically un-African.

\section{Conclusion}

One can state with emphatic authenticity with Professor Maduabuchi Dukor (148) that "postcolonial and contemporary developments and modernist dispositions in Africa have brought with them additional problems to feminism. According to Professor Dukor, "such problems as women abuse with clubs and kanes, excessive rate of divorce, marital litigations, women slavery to foreign countries, rape, sexual harassment, the class struggle between men and women were added dimension in the plight of women in Africa; the problem of gender discrimination either does not exist in African social structure or culture or is not understood properly as post colonial social and ontological aberration. This is the reason for the current investigations into gender related concepts historically and contextually in Black Africa”. This African perspective and inquiry into the challenges facing gender injustice and mainstreaming will "go beyond the political, sociological, anthropological and cultural approaches that gloss the existential import of every status, desert and relational calculus that underline the creative and justiceable relations between man and woman and consequent interests, actions and abuses”.

\section{REFERENCES}

Dukor, M. (2002). Philosophy and politics: Discourse on values, poli- 


\section{A. CASIMIR}

tics and power in Africa. Lagos: Malthhouse Press.

Dukor, M. (2010). African philosophy in the global village. Theistic pan-psychic rationality, axiology and science. Saarbrucken: Lambert Academic Publishing.

Idowu, E. B. (1975). African traditional religion, a definition. Great Brittain: SCK Press.

Igboin, B. O. (2011). Colonialism and African cultural values. African Journal of History and Culture, 3, 96-103.

http://www.academicjournals.org/ajhc

Kwame, G. (1996). African cultural values-an introduction. Lancing: Sankofa Pub Co. As quoted by Lolli, Around the world blog.
Lassiter, J. E. (1997). African culture and personality: Bad social science, effective social activism, or a call to reinvent ethnology? African Studies Quaterly, 3, 1.

Oko, E. O. (2004). Human rights and the African indigenous justice system. Paper for Presentation at the 18th International Conference of the International Society for the Reform of Criminal Law, 8-12 August, Montreal.

Oraegbunam, K. E. (2011). The principles and practice of justice in traditional Igbo jurisprudence.

http://www.ajol.info/index.php/og/article/viewFile/52335/40960 